\author{
(online) $=$ ISSN $2285-3642$ \\ ISSN-L = $2285-3642$ \\ Journal of Economic Development, Environment and People \\ Volume 5, Issue 1, 2016 \\ URL: http://jedep.spiruharet.ro \\ e-mail: office jedep@spiruharet.ro
}

\title{
Foreword
}

\section{Changing Economy - developing key skills for a new attitude}

Go with the times or be gone in no time $e^{1}$

Our economy and society is marked by very rapid changes. We live in times of permanent changes in a breathtaking pace. This is accompanied by uncertainty, anxiety and general lethargy. We can recognize Phenomena such as these not only at individuals - undisputed right at each of us in varying degrees - but it also relates to all sectors, such as the economy, politics, society in its various areas.

In times like these, however, it would be necessary exactly the opposite. An attitude is required to accept seriously the challenges of the future rather than care for a comfort Soothing zone or turn to the inner peace like the motto "Let the storm pass me by" or pursue an optimism that promises it will always go on as all the years before also.

What qualities would be therefore necessary in a changing economy? Above all there are three characteristics of a new attitude, without which we cannot cope with the challenges of the future such as energy policy, globalization, demographics, diversity, scarcity of raw materials, etc.. These three features required for a new attitude in changing economy are: authenticity, transparency and dialogue. This may sometimes ring trite, but we can look closer. Never before people were able to handle with so much information. The Economy 4.0 is a real challenge for the future. The new media like the Internet and the social networks allow a large number of people to be informed and to have an independent opinion. Their criticism has increased in particularly, so that they developed a fine sense for fairly and honestly trade. Everything gets near rip, manipulation or deception are quickly considered hazardous and therefore rejected.

Only those who deal authentically with its stakeholders, will be able to build or maintain its reputation as a reliable partner. Closely related to the authenticity is the transparency. The information era allows many people and NGOs (non governmental organizations) to access a wide range of numbers, figures and facts about business, politics, etc.. The attention is given in terms of sustainability. The sustainability stays next to price in sales decision. Who advertises with social projects, but then has to justify for exploitative wages, has a serious credibility problem.

${ }^{1}$ Friedrich Schiller (1759 - 1805), german dramatist, poet and historian 


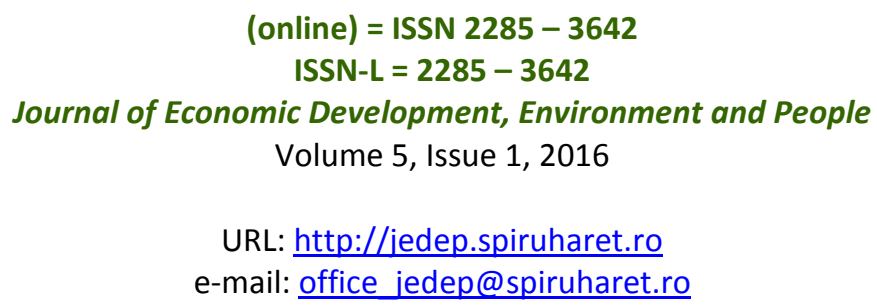

The economy is increasingly more have the responsibility to observe social linings and contribute to the correction of irregularities. The sustainability efforts must keep this direction, although not always with sufficient consequences and credibility. Conversely, society and politics will do it's best to create the optimal frameworks for the economy - not only for the preservation and creation of jobs, but of assurance of the balance of the social climate in the country in general.

The current issues of journal of Economic Development, Environment and People (JEDEP) presents very important subjects for the economic debate: Eco industrial Development: as a way of Enhancing Sustainable Development (B. Sertyesilisik, E. Sertyesilisik), New Trends in Economic Globalization (E. Gurgu, A. Cociuban), the Evaluation of Working Capital in Airline Companies which proceed in Bist (S. Kendirli, A. Kaya), an Essay on the Applicability of the Lindner Hypothesis in Determining the Patterns of the Romanian International Trade (T.G. Viciu, L. Mihoreanu, C. Costea), Activ social Programs and Their Strategic Advantages in Labor Market Development ( $E$. Stoyanov), the Effects of Right Offering Announcements on Returns of Shares of Deposit Banks Traded in Istanbul Stock - Exchange (S. Kendirli, M. Emin Elmali), Contributions to the Analysis if Amendments of the Crime Stipulated in Art. 43 of Law nr. 255/1998 on the Protection of New Varieties of Plants Made by Law no.187/2012 for the Enforcement of Law no. 286/2009 on the Criminal Code (B. Florea).

Raluca M. Mihalcioiu, PhD 